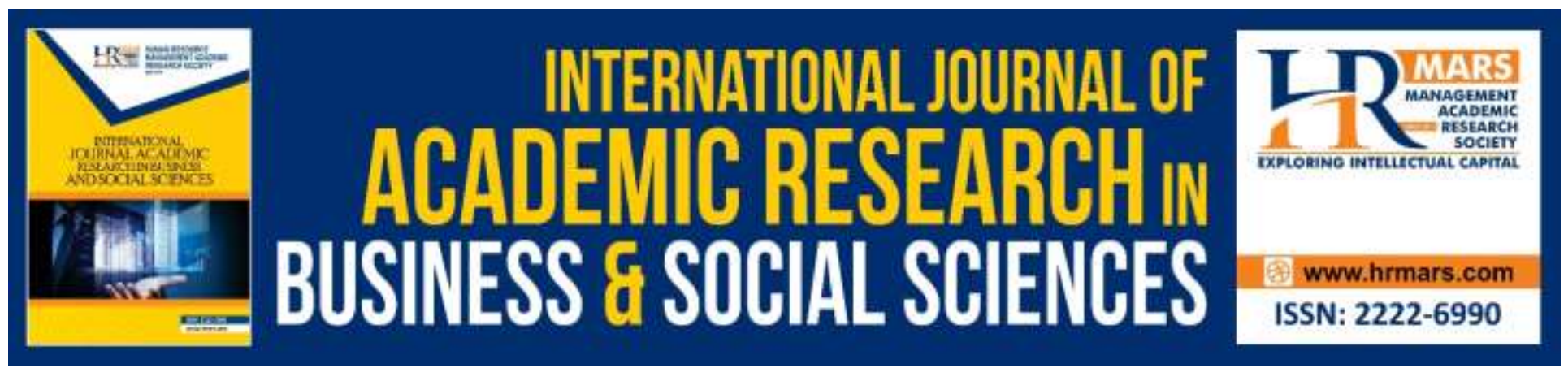

\title{
Authority of Regulation and Supervision Banking and Financial Services Authorities
}

\author{
Bambang Panji Gunawan, Surti Yustianti, Abdul Majid Tahir Mohamed, \\ Suyatno
}

To Link this Article: http://dx.doi.org/10.6007/IJARBSS/v9-i7/6087

DOI: $10.6007 /$ IJARBSS/v9-i7/6087

Received: 12 May 2019, Revised: 07 June 2019, Accepted: 23 June 2019

Published Online: 13 July 2019

In-Text Citation: (Gunawan, Yustianti, Mohamed, \& Suyatno, 2019)

To Cite this Article: Gunawan, B. P., Yustianti, S., Mohamed, A. M. T., \& Suyatno. (2019). Authority of Regulation and Supervision Banking and Financial Services Authorities. International Journal of Academic in Research Business and Social Sciences, 9(7), 10-16.

Copyright: (c) 2019 The Author(s)

Published by Human Resource Management Academic Research Society (www.hrmars.com)

This article is published under the Creative Commons Attribution (CC BY 4.0) license. Anyone may reproduce, distribute, translate and create derivative works of this article (for both commercial and non-commercial purposes), subject to full attribution to the original publication and authors. The full terms of this license may be seen

at: http://creativecommons.org/licences/by/4.0/legalcode

\section{Vol. 9, No. 7, 2019, Pg. 10 - 16}

http://hrmars.com/index.php/pages/detail/IJARBSS

JOURNAL HOMEPAGE

Full Terms \& Conditions of access and use can be found at http://hrmars.com/index.php/pages/detail/publication-ethics 


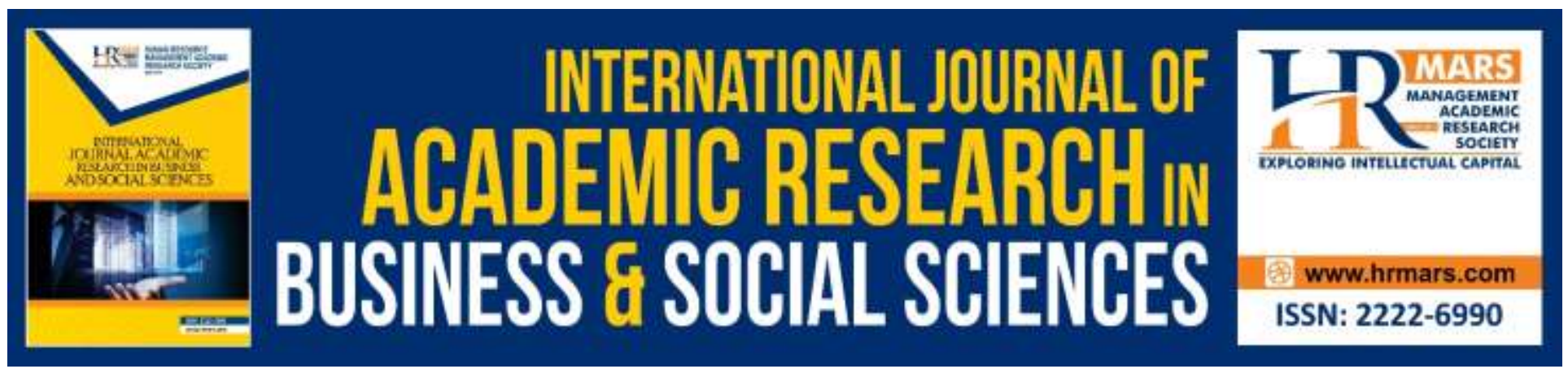

\title{
Authority of Regulation and Supervision Banking and Financial Services Authorities
}

\author{
Bambang Panji Gunawan ${ }^{1}$, Surti Yustianti², Abdul Majid Tahir \\ Mohamed $^{3}$, Suyatno 4 \\ ${ }^{1}$ Lecturer Universitas Maarif Hasyim Latif, Surabaya. Indonesia, ${ }^{2}$ Universitas Merdeka Surabaya, \\ Indonesia. ${ }^{3,4}$ Lecturer Universiti Sultan Zainal Abidin, Terengganu. Malaysia
}

\begin{abstract}
This study analyzes the regulatory and supervisory authority of banks conducted by the Financial Services Authority set out in Law no. 21 of 2011, which was previously undertaken by Bank Indonesia, to apply the principles of prudence and good faith principles to banks to prevent the risk of banking crime. Banking supervision and regulation after the issuance of the Financial Services Authority Law, Bank Indonesia, as the central bank only acts as a monetary policy regulator to maintain monetary stability. The problem in this research is about the concept of law of regulation and supervision of the banking sector by the Financial Services Authority and how the legal relationship with Bank Indonesia. The type of research used is juridical normative, then the data used secondary data and primary data, the approach in this study using a conceptual approach, and comparative approach. Bank Indonesia's regulatory and supervisory duties transferred to Financial Services Authority are only related to micro-prudential, and the banking arrangements by Bank Indonesia are still conducted by Bank Indonesia only macro-prudential, while the regulation of banking by Financial Services Authority is not fully independent.
\end{abstract}

Keywords: Authority, Bank Indonesia, Legal Relations And The Financial Services Authority

\section{Introduction}

The presence of a bank is very closely related to developments in the field of trade. The life of the modern world today cannot be released and often depends on banking activities and services. Provisions of Article 34 of Act Number 3 of 2004 concerning Amendments to the Law of the Republic of Indonesia Number 23 of 1999 concerning Bank Indonesia this regulation mandates the establishment of financial service sector oversight institutions that include banking, insurance, pension funds, securities, venture capital, and finance companies as well as agencies that administer public funds. This policy was taken in view of the many problems in the banking sector that had a crisis that affected 21 (twenty-one) crisis national private banks liquidated by Bank Indonesia, which found various deviations so many questioned Bank Indonesia's supervision. Likewise, there was an unexpected event that Bank Indonesia set bank Century as a failed bank with a systemic impact. The 
many problems in the financial services sector in the banking sector, which could disrupt financial system stability further encouraged the need for the establishment of supervisory institutions in the integrated financial services sector.

Since December 31, 2012, the enactment of Law Number 21 Year 2011 concerning the Financial Services Authority (from now on referred to as the Financial Services Authority Law), shows that Indonesia will enlarge in applying the supervision model to its financial industry. The functions, duties, and authority of regulating and supervising financial service activities in the Banking sector are shifted from Bank Indonesia to the Financial Services Authority (Article 33 paragraph (2). Every official always makes policies in various fields. The policy is given a different meaning by Harold D. Lasswell, and Abraham Keplan interpreted the policy as "a projected program of goals, values, and practices." The policy is defined as a series of actions that are established and implemented or not implemented by a government that has a specific goal or orientation for the benefit of the whole community (Irfan, 2003).

This is important so that the authorities, as decision-makers, should not be trapped in a momentary policy, so that it cannot last for the long term (Nawawi, 2008). Bank Indonesia's policy that mandates the establishment of supervisory institutions in the financial services sector is expected to improve the framework financial system I tougher. With the promulgation of the Financial Services Authority Law, there will be a unification of the regulation and supervision of the financial services sector, where previously the authority for regulation and supervision was carried out by the Ministry of Finance, Bank Indonesia, and the Capital Market Supervisory Agency and financial institutions. In the Financial Services Authority Law, it is regulated with sufficient detail on the provisions governing the transition so that the task shifting and regulatory and supervisory functions run well.

The problem discussed in this study is the legal concept of the authority to regulate and supervise financial institutions in the activities of financial services in the banking sector by the Financial Services Authority and Bank Indonesia. Based on this, a separate institution to regulate and supervise banks is expected to have good synergy and coordination by Bank Indonesia and the Financial Services Authority. Thus the existence of the Financial Services Authority can bridge the interests between Bank Indonesia and the Ministry of Finance.

\section{Literature Review}

This study of Lestari (2012) discusses the establishment of the Financial Services Authority, which aims to ensure that all activities in the financial services sector are organized regularly, fairly and transparently. A new institution has been born by Law Number 21 of 2011 concerning the Financial Services Authority. With the existence of this Law, the Financial Services Authority has enormous authority in regulating and supervising the financial services sector. Financial Services Authority's task is to monitor and supervise the three financial services sectors, namely the banking sector, capital market sector, and the insurance sector. Financial Services Authority has the authority to regulate and supervise bank institutions and conduct bank checks. Thus, licensing issues for the establishment of banks, as well as revocation of bank business licenses are under the authority. 
Furthermore, the study of Murdadi (2012) which discusses an independent financial services institution in addition to having authority in the regulation and supervision of financial institutions, mainly banks in Indonesia, also has the authority to investigate. The authority of investigation in the task of banking supervision is a new thing since the Republic was founded. In addition to this, what is new is that the operational costs of these independent institutions can be collected from supervised financial institutions, including banks. Amid the euphoria of eradicating corruption, this condition is certainly very vulnerable to vested-interest and "counter-achievement demands" among these institutions. Also, if banks are subject to fees/fees, they will certainly encourage higher banking operational costs and lead to an increase in lending-costs for banks as a whole. In the end, it can also hamper the empowerment of the national economy.

Furthermore, Maulidiana (2016) discusses As a banking supervisory institution in Indonesia Financial Services Authority has the function of organizing a micro-prudential regulatory and supervisory system. Regulation and supervision of institutional, health, prudential aspects and bank checks are the scope of micro-prudential regulation and supervision, which is the duty and authority of the Financial Services Authority. The scope of macro-prudential regulation and supervision is the duty and authority of Bank Indonesia. In the context of macro-prudential regulation and supervision, the Financial Services Authority is assisting Bank Indonesia to conduct moral advice to banks. To the Financial Services Authority that the independence of the Financial Services Authority in carrying out its functions, duties, regulatory authority, supervision, inspection and investigation that are legally free from interference from other parties can be carried out properly by the expected without any intervention from other parties.

\section{Research Methodology}

This type of research is based on legal research. Jimly (2009) stated that Law is the norm and norm that exists in society, so the consistency of the type of research used is the type of normative legal research. The approach in this study is used to examine existing problems, namely the statute approach, the conceptual approach. The source of legal material from this study is in accordance with the nature of normative legal research, legal material which is the basis for the study of legal issues of this study consists of primary legal material and secondary legal material. Primary legal material is the subject of reviewing Law Number 23 Year 1999 concerning Bank Indonesia as amended by Act Number 3 of 2004 concerning Bank Indonesia concerning Amendment to Law Number 23 Year 1999 concerning Bank Indonesia (hereinafter referred to as Bank Indonesia Law), Act Law Number 21 Year 2011 concerning Financial Services Authority. Secondary legal materials provide an explanation of primary legal materials, including the work of the law, journals, scientific magazines, the internet, and views or doctrines related to the literature and principles of the banking actors and the Financial Services Authority. Based on explanation above, this research used primary legal material and secondary legal material because is relevance with with the nature of normative legal research. 


\section{Result}

The establishment of the Financial Services Authority based on Law Number 21 of 2011 concerning the Financial Services Authority is an independent institution in supervision in the banking sector. With the existence of a separate institution in banking supervision, it is hoped that there will be good information and coordination between regulatory and supervisory institutions between Bank Indonesia and the Financial Services Authority. The task of Bank Indonesia with the issuance of the Financial Services Authority Law is that it no longer supervises individual banks, but rather oversees macroprudential aspects, namely supervision of systemic risks to financial system stability. Thus the policy regulation stipulates that Bank Indonesia's duties are still heavy in accordance with the Bank Indonesia Law, among others, maintaining monetary stability and regulating the payment system and overseeing the capital market and non-bank financial institutions, aiming to ensure the risk of financial system stability in the field of banking.

By looking at the foregoing description that there is a legal relationship between banks as the party supervised by Bank Indonesia, the Financial Services Authority as the supervisory party and this is regulated in Law Number 7 of 1992 concerning Banking as amended by Law Number 10 Year 1998 concerning Amendments to Law Number 7 of 1992 concerning Banking (hereinafter referred to as the Banking Law), Bank Indonesia Law and Financial Services Authority Law. The core objective of bank supervision is to protect customers who deposit and entrust their funds in banks. Talking about the protection of victims, how is the politics (policy) of current criminal law, whether protection of victims is regulated in positive criminal law. However, with the existence of Law Number 24 of 2004 concerning the Deposit Guarantee Institution, the authority of Bank Indonesia if there is a bank that cannot be rescued will surrender the fate of the bank to the Deposit Insurance Corporation. As an effort to improve the bank supervision system, especially in the context of increasing the effectiveness of bank supervision, Bank Indonesia applies forward-looking risk-based bank supervision.

The existence of Bank Indonesia, both from its position, functions and duties, its authority, has been regulated in the provisions of the Bank Indonesia Law. In this study, specifically examine the articles governing the duties and authorities of Bank Indonesia, which have now been transferred to the Financial Services Authority. The articles that authorize Bank Indonesia Officials to have authority in making policy on problems in the banking sector, whose scope of macro-prudential regulation and supervision, namely regulation and supervision other than those stipulated in Article 7 of the Financial Services Authority Law is the duty and authority of Bank Indonesia. Macroprudential regulation and supervision which is the task of banking regulation, by developing macro-prudential analysis methods that will later evaluate the health, strengths, and weaknesses of the financial system in Indonesia, and be published in periodic financial stability studies to the public about the impact on the financial system in the event of a crisis. The task of banking regulation is not fully implemented independently by the Financial Services Authority, because the arrangement of banking tasks and supervision, both micro-prudential and macroprudential are interrelated. The Financial Services Authority only helped Bank Indonesia to make moral calls to banks. Bank Indonesia's policies as part of the Indonesian financial system and payment system have an important role in controlling and maintaining the balance of national banking. 
Article 6 of the Financial Services Authority Law states that the Financial Services Authority carries out the duties of regulation and supervision of:

a. Financial service activities in the banking sector;

b. Financial service activities in the Capital Market sector; and

c. Financial service activities in the Insurance, Pension Fund, Financing Institutions, and Other Financial Services Institutions sectors.

The establishment of the Financial Services Authority is a mandate of Article 34 of the Bank Indonesia Law, where there is a division of duties in carrying out banking supervision, namely the task of supervising banks carried out by the Financial Services Authority. The tasks given by the Law to Bank Indonesia cannot be separated from the objectives of Bank Indonesia. The Bank Indonesia Law stipulates the objective of Bank Indonesia is to achieve and maintain the stability of the rupiah value. The stability of the rupiah's value is very important to support sustainable economic development, which in the end is to improve people's welfare. The stability of the rupiah value is the stability of the rupiah value of goods and services, and stability of the rupiah exchange rate. Exchange rate stability is measured by the development of the rupiah exchange rate against the currencies of other countries. It should be borne in mind that exchange rates are not entirely dependent on mere economic conditions.

Political and social issues also have a strong influence on the stability of the rupiah exchange rate against the currencies of other countries. The duties and functions of Bank Indonesia, which are directly related to Banking are to have a lender of last resort function, as formulated in Article 11 of the Bank Indonesia Law. If possible for Bank Indonesia to provide credit or payment based on sharia principles, in order to assist the difficulties of short-term funding that is being faced by the bank. The assistance was given because there had been a mismatch, namely the incompatibility between the inflow of funds and the outflow of funds, namely that the inflow of funds was smaller than the outflow of funds.

The provisions concerning the provision of credit or financing on the basis of sharia principles are carried out by Bank Indonesia by remembering the following matters:

1. Banks experience mismatch either due to credit risk, financing risk based on sharia principles, management risk or market risk;

2. Banks have collateral that is of high quality and easily liquidated;

3. Given no more than ninety days (calendar days). The period is "maximum" meaning that it includes the extension;

4. If the bank is unable to pay off at maturity, Bank Indonesia has the right to withdraw the collateral; 5. Determination of certain interest rates by Bank Indonesia, among others, in the framework of credit from Bank Indonesia and in the implementation of the functions of lender of last resort.

With the enactment of Law Number 9 of 2016 concerning Prevention and Handling of Bank Problems in the Financial System Crisis, Article 37 A Act No. 10 of 1998 concerning Amendments to Law No.7 of 1992 concerning Banking and Article 11 paragraph (4) and (5) Law No. 23 of 1999 concerning Bank Indonesia and Article 44 - 46 and Article 69 paragraph (3) Law No. 21 of 2011 concerning the Financial 
INTERNATIONAL JOURNAL OF ACADEMIC RESEARCH IN BUSINESS AND SOCIAL SCIENCES

Vol. 9, No. 7, July, 2019, E-ISSN: 2222-6990 C 2019 HRMARS

Services Authority is declared invalid. Thus if a bank experiences a breakdown or failure, the Financial Services Authority and Bank Indonesia coordinate to determine the Bank in a systemic state.

\section{Conclusion}

The task of Banking Regulation and Supervision is carried out between Bank Indonesia, together with the Financial Services Authority. Bank Indonesia currently implements bank supervision on a consolidated basis, for that the integration of financial services supervision will strengthen monetary policy and strengthen financial system stability in Indonesia. The establishment of the Financial Services Authority will have an impact on the implementation of duties and its authority in the banking sector, which must be carried out optimally. Although the task of regulating and supervising banks has shifted from Bank Indonesia to the Financial Services Authority, Bank Indonesia still has authority and access to data and information from banks.

With the establishment of banking regulations and supervision systems by the Financial Services Authority, there must be clear guidelines on the principles of the Financial Services Authority so that there is no risk to the stability of the banking system given that the precautionary principle must be interpreted. as a way to prevent systemic impacts. and moral hazard, because the Financial Services Authority is a new institution that has no experience like Bank Indonesia. The existence of the Financial Services Authority requires a lot of money, in order to improve human resources, considering that funds outside Bank Indonesia originate from the state budget, because of the limited costs that can disrupt the banking supervision system while Bank Indonesia, whose budget comes from own funds. Banking supervision will not be hampered by budget constraints.

\section{References}

Arif, B., \& Nawawi. (2008). Kebijakan Hukum Pidana, Perkembangan Penyusunan Konsep KUHP Baru. Jakarta. Kencana Persada Muda Grup.

Asshidiqie, J. (2009). Pengantar Ilmu Hukum Tata Negara. Jakarta. Raja Grafindo Persada.

Islamy, M. I. (2003). Prinsip-prinsip Perumusan Kebijaksanaan Negara. Jakarta: Bumi Aksara.

Lestari, D. H. (2012). Otoritas Jasa Keuangan: Sistem Baru dalam Pengaturan dan Pengawasan Sektor Jasa Keuangan. Jurnal Dinamika Hukum, 12 (3) 558-567

Maulidiana, L. (2016). Principles of Al-Mudharabah: A Review Islamic Banking Agreements In Indonesia (Case Study Of Bank Rakyat Indonesia Syariah). 1 (1) 1-9

Murdadi, B. (2012). Otoritas Jasa Keuangan (OJK) Pengawas Lembaga Keuangan Baru Yang Memiliki Kewenangan Penyidikan. 8 (2) 32-46 